JPPUMA: Jurnal Ilmu Pemerintahan dan Sosial Politik UMA (Journal of Governance and Political Social

UMA), 8 (1) (2020): 37-46, DOI: https://doi.org/10.31289/ippuma.v8i1.3129

JPPUMA: Jurnal Ilmu Pemerintahan dan Sosial Politik UMA

(Journal of Governance and Political Social UMA)

Available online http://ojs.uma.ac.id/index.php/jppuma

\title{
Infringement of General Election Ethics in Riau Islands Province, Indonesia
}

\author{
Barta Oktarius Barus*, Arry Bainus \& Muradi \\ Political Science Study Program, Faculty of Social and Political Sciences \\ Universitas Padjajaran, Indonesia
}

Recieved: November 29, 2019; Accepted: February 21, 2020; Published: May 11, 2020

\begin{abstract}
Violation of ethics that involves the General Election Committee members is due to less concern to the process of the development of democracy. Several cases show that the organizers of the election went to the ethics trial of the Honorary Council of Election Management Bodies (Dewan Kehormatan Penyelenggara Pemilu, DKPP). This research analyzes the factors that cause the violation of ethics in the General Election in the Riau Islands province. This study applies qualitative methods and managed some interviews, field visits, and library research to collect data. This study employs the theory of institutional capacity from Christensen and Gazley (2008) to analyze the collected data. The theory views the institution from four dimensions to identify the problems in the violation of ethics, namely, human resources, external factor, infrastructure, and financial. Human resources as the organizers of the general election know less the regulation and manuals that regulate the election, which results in the violation of ethics. This study seeks to know the factors that cause the violation so it can contribute to the general election's organizers to improve their knowledge and organize the election with integrity.
\end{abstract}

Keywords: Ethics, integrity, General Election Committee, General Election.

How to Cite: Barus, B.O Bainus, A \& Muradi (2020). Infringement of General Election Ethics in Riau Islands Province, Indonesia. JPPUMA: Jurnal Ilmu Pemerintahan dan Sosial Politik UMA (Journal of Governance and Political Social UMA), 8(1): 37-46.

*Corresponding author:

ISSN 2549-1660 (Print)

E-mail: barta.kpu @gmail.com

ISSN 2550-1305 (Online) 


\section{INTRODUCTION}

General Election is an important process to develop a democratic system. According to the Indonesian constitution, public trust in the political process such as General Election will legitimate power. Therefore, the state as the organizer of the election has to guarantee the transparency, fairness, and integrity of a General Election. The implementation of an election, following the principles of democracy, depends on the organizers, the General Election Committee.

The organizers of the General Election at all levels have to be professional and free from any intervention from any interest groups (Sardini, 2016). The organizers should have knowledge and experience to analyze and to be responsive to the unpredictable problems that appear in the implementation of the election (Rahardjo, 2010). Further, the organizers also have to maintain their integrity and independence in doing their tasks to serve quality election to the people.

The implementation of the general election in Indonesia shows that one of the factors that degrade the integrity of the organizers is their low capacity. This leads to the incapability to organize a fair, integrated, and transparent general election following the ethics (York, 2010).

The Honorary Council of Election Management Bodies (Dewan Kehormatan Penyelenggara Pemilu, DKPP) reveals that there are 1658 cases of violation of the ethics between 2012 and 2015 throughout Indonesia. Some of the cases took place in some parts of the province of Riau Islands, namely Tanjungpinang, Batam, and Tanjung Balai Karimun. (source: www.dkpp.go.id accessed on 21 January 2019).

First of all, this research describes the previous studies on the violation of ethics in the general election in the Riau Islands. Zetra (2017), studied the violation of ethics codes in the frame of the social and political perspectives, from the perpetrators' point of view that brings them to the violation of the law. Specific cases that he observed are Legislative Election and Local Election. Some cases are, for example, swapped ballot papers in which there is no re-voting Pemungutan Suara Ulang (PSU) to redeem it. Ethics violations that Local Committee of General Election KPU Kabupaten/Kota in West Sumatra, for instance, is due to less knowledge on the implementation of the general election.

The other research has been done by Pratama (2017). This study reveals that the integrity of the organizers of the General Election can be measured through several factors, namely, independence, impartiality, efficiency, proportionality, and transparency. Further, Rizal (2017) through his study states that the improvement of quality of democracy needs the state institutions to monitor the process of the General Election in Indonesia to promote the modern ethics of the election such as transparency.

The similarity of this study with the previous ones is in the normative view that looks at the consequences of the violation, in which the organizers have to hold responsible in the special court of General Election's ethics. Wheres, the differences are that this research is not an investigation but it deals with the capacity of human resources, their professional attitudes to maintain their integrity in the implementation of the General Election.

Based on the background of this study, there are three locations that the author chose, namely Batam city, Tanjungpinang city, and Tanjung Balai Karimun District. There is some consideration to choose the locations, namely, from many cases of violations in the general election in Riau Islands province (in six districts), cases in Batam, Tanjungpinang, and Karimun appear in public. 
This research studies the Legislative Election in 2014 and Gubernatorial Election in 2015 in Riau Islands. Generally, the process begins from the violation of the Legislative Election in Tanjungpinang city, which is an ethics violation and criminal. The criminal conduct is the mark up of votes at the lowest level oft he organizer (Panitia Pemungutan Suara/ PPS). This case is closed by the supervisor at the city level (Panwaslu Kota Tanjungpinang). However, people have submitted a lawsuit.

In Batam, the organizers of the General Election brought ballot boxes to one of the hotels without any supervision and any escort from security staff. This has been suspected to have marked up the votes. Whereas in Karimun District, the organizers of the election ignored the recommendation from the Supervisor (Panwaslu) to organize re-voting. Another indication is the violation of ethics, which is bad manners oft he organizers of the election to the participants of the election during the plenary meeting.

From the above problems, this research aims to analyze the factors and the cause of the violation of ethics of the general election that involve the organizer of the general election in the implementation of the Legislative Election in 2014 and Gubernatorial Election of Riau Islands in 2015.

\section{RESEARCH METHODS}

This research applies qualitative methods. The research narrows down ist focus on particular cases of violation of ethics of general election taking place in the Riau Islands. The first case if the Legislative Election in 2014. While the second case is the Gubernatorial Election of the Province of Riau Islands in 2015.

Creswell (2015) explains that qualitative research always considers research ethics. Ethics is an important aspect to develop arguments or views in selecting topics to be chosen for writing. In this sense, the researcher should keep information about his/her informants who do not want his name to reveal to the public. This means that the researcher has to be careful in keeping the reputation of informants or any organizations whose information that might contradict the interests of other informants or organizations that can stimulate conflict. In this respect, the researcher has to be careful and wise in dealing with such problems (Israil \& Hay in Creswell, 2013).

To collect data, the author manages a series of interviews and an in-depth interview with several informants. The author selects some key informants, such as the members of the General Election Commission (KPU) and the General Election Supervisor (BAWASLU) at the district or municipal level, who were suspected to have violated ethics of general election by DKPP. The author employs qualitative methods to view problems as a whole. The author formulated problems, research questions, and managed data collection, data analysis, and wrote a report (Bogdan, 1975).

\section{RESULT AND DISCUSSION \\ Identifying the Causes of Violation of General Election Ethics}

This research observes the situation in the implementation of the General Election. One of the factors that contribute to the loss of integrity of the organizers of the General Election is their low capacity. The fair and good reputation of the General Election cannot be achieved in this case. The low capacity means the capacity of the organization (General Election Commission) to pursue its goals does not correspond with its integrity due to taking aside to one of the participants of the election (York, 2010).

In the implementation of the General Election in 2014 in Riau Islands, The Honorary Council of Election Management Bodies (Dewan Kehormatan Penyelenggara Pemilu, DKPP) received six 
reports from General Election Supervisor (Badan Pengawas Pemilu/BAWASLU) about the violation of ethics. The organizations that are suspected to be committed in these cases are General Election Supervisor at the district level (Panwaslu Kota Tanjungpinang), the General Election Commission (KPU) Kota Batam and General Election Commission (KPU) Kabupaten Karimun (Source: BAWASLU Provinsi Kepulauan Riau).

In order to reduce the cases of an ethics violation, the government has attempted to enact rules that regulate the code of conduct for the organizers of the General Election. Yet at the national level, the reports sent to the Secretariat of DKPP from 2012 to 2019 increased constantly.

In the implementation of the General Election, DKPP receives about 3666 cases of ethics violation within the period of eight years in 2019. Only in 2012, the reports declined in the outright implementation of Local Election in Indonesia. From 3666 cases reported to DAKK, only 40 percent went to the trial. The decline as mentioned above is connected to the Local Election in 2015. In Riau Islands, there are five districts (Kabupaten/Kota) that held Local Election at the district level except for Tanjungpinang. This city held the Local Election for Mayor in 2017.

\section{Problems and Solution of Ethics Violation in Gubernatorial Election in Riau Islands in $\mathbf{2 0 1 5}$}

Processes that take place in the Gubernatorial Election in Riau Islands cannot be separated from the violation of ethics. The stages of the nomination of candidates according to the schedule made by KPU started from 8 till 12 June 2015. KPU of Riau Islands Province assigned the two pairs of candidates who run in the election, namely: 1) Drs. H. Muhammad Sani dan H. Nurdin Basirun, S.Sos; dan 2) Drs. H.M Soerya Respationo, SH., MH dan H. Ansar Ahmad, SE., MM
A group of people considered that one $o$ the above candidates did not meet the requirements for being a candidate due to having an illegal school certificate. The group reported the stipulation of candidates that the KPU Province of Riau Islands managed. Someone named Humaldi reported this case that was registered in DKPP with numbers, Nomor 193/I-P- DKPP/2015 dated 2 November 2015. Humaldi himself is a lecturer at one of the local universities and is also an activist in NGO Keris. His report is related to the legality of school certificate, at the level of High School, owned by one of the candidates in the name of Nurdin Basirun. The report demanded KPU Provinsi Kepulauan Riau to stipulate that the name is not eligible Tidak Memenuhi Syarat (TMS) to participate in the Gubernatorial Election in 2015.

The reporter, in this case, suspects that the KPU Province of Riau Islands violates the rules due to accepting the candidacy of Nurdin Basirun as a candidate of Deputy Governor. Humaldi argues that the documents of candidacy submitted to KPU are not eligible. He argues that the verification process that KPU managed was invalid and not eligible.

In my investigation to the members of the General Election Commission (KPU) of the Riau Islands, the commission has tried to improve the organizational capacity to increase its integrity. The capacity building is including the human resources and management system. This involves the top rank, commissioners, who are trained to work in collective and collegial. While, the members of the secretariat or administrative section are trained to form a working group or unit that can work and solve the problems they are facing (Newstrom \& Davis, 2000).

The capacity they develop is the responsiveness to the situation and to seek solutions. For example, in the registration process, the problems that appeared at this stage is not only delegated to the 
division of candidacy to solve. The organization of the General Election Commission has to solve the problem by involving the other division and external organizations cooperatively related to issues of candidacy.

With the involvement of external organizations whose expertise related to the problems that KPU is facing, the General Election Commission can overcome the report sent to DKPP by the NGO. For example, the dispute over school certificate suspected illegal could be solved by the cooperation with any related institutions. It is due to the external organization such as school or Department of Education can validate and verify the certificate. In the case of Nurdin Basirun is the Directorate of Sea Transportation at the Ministry of Transportation Affairs and the Department of Education.

In this case, DKPP concluded to refuse the report as a whole and rehabilitate the integrity of the General Election of Riau Islands. This is also related to the assertion that contests an individual, personnel of the Commission, not the organization. Even though the report should have reported the organizer of the election, General Election Commission, due to this organization makes any decision collectively.

\section{Problems and Solution in the Violation of Ethics in the General Legislative Election in 2014}

The violation of ethics by the organizers also happened in the implementation of the Legislative Election in 2014 in Riau Islands Province. Of seven district/municipality in the province, the violation has been found in three districts. They have received also the verdict from DKPP. Media exposed that the cases on which DKPP has had resolution involved also the organizers of the General Election such as General Election Commission (KPU) and the Supervisor of General Election (BAWASLU).
In Tanjung Pinang, a commissioner of PANWASLU (supervising body at the district level) was suspected to have committed in the violation. This is said to be connected with the ignorance of one of the members of the supervising body in the process of recapitulation of votes in one of the areas in the city. Besides violating ethics, the organizer was also reported to have conducted crime related to General Election (tindak pidana Pemilu).

The report says that the member of the supervising body (PANWASLU) did not pass the society's report to DKPP and ignore the conduct suspected crime, namely marking-up votes. In that case, one of the legislative candidate's claims of being aggrieved due to his votes has been stolen and given to his rival. Related tot he violation of ethics, DKPP decided to fire the member of PANWASLU who has the initial name $\mathrm{BH}$ from his office.

Allegation of ethics violation that has been reported also happened in Kota Batam. A lawsuit has been accepted by DKPP with registration number 70/DKPPPKE-III/2004. It said that the violation of ethics is related tot he marking-up votes for one of the candidates. There is also a case in which the organizers of the General Election had brought the documents of votes record and changed them. This has violated the ethics and procedures of the General Election (Source: DKPP's verdict, 2014).

Pelanggaran kode etik yang ketiga terjadi di Kabupaten Karimun yang melibatkan Komisioner KPU Kabupaten Karimun. Pelaporan pelanggaran kode etik tersebut dilaporkan oleh salah satu peserta pemilu terkait Penghitungan Rekapitulasi Suara di lingkup kelurahan yaitu kelurahan Sawang di kecamatan Kundur Barat dan kelurahan Alai di kecamatan Ungar di Kabupaten Karimun.

The report on the above cases has been accepted and registered in the DKPP secretariat with number 96/I-P/LDKPP/2014. The report sue all members of 
PANWASLU due to ignoring the recommendation to remedy the recapitulation of votes. According to witnesses, the meeting of recapitulation was suspended temporarily due to blackout. It continued later with the plenary meeting in the light from the handphone. Besides, there is an error in the recapitulation of votes. Moreover, the chief of the General Election Committee (KPU) was said as arrogant to the participant of the meeting. He was witnessed to wear a T-shirt in the plenary meeting and sounded arrogant with a loud voice, which is said to be impolite and did not respect the participants oft he plenary meeting (sumber DKPP RI).

\section{The Capacity of General Election Agencies}

The general election agencies have a major role in attempts to improve the quality of democracy through the general election. An approach to the institutional capacity is needed to minimize violation of ethics through upgrading the quality of human resources. In this sense, the personnel in the institution can maintain their credibility as the organizers of the general election.

This approach looks at the organizers of the general election from the very start of the establishment of the institution and the recruitment process of its personnel. The approach also takes into account the whole carrier of the personnel until the end of their tasks according to the regulation of the general election.

Christensen \& Gazley (2008) make a guideline to analyze the capacity of general election agencies from the dimension of human resources, external influence, infrastructure, and financial aspect, and mission and vision oft he organizations.

The aspect of human resources ist he most important in the process of the implementation of the general election with fairness, transparency, and integrity. This emphasis on the person of the organizers of the general election itself. The personnel of the general election agencies could be said as human resources in the implementation of the general election.

In order to improve the quality of general election according to rules, it needs to improve the capacity of the personnel of the organizers themselves. The improvement can start from a personal level or due to external influence. Personal initiatives are, for example, by learning from other colleagues, reading literature and regulations, and from discussions with other colleagues. Whereas, the external influence come from training organized by other General Election agencies.

This dissemination of knowledge will improve the personnel who cannot reason that they do not know regulations. One of the causes of violations is less knowledge about regulations made by General Election Committee at the central level. For example in Tanjung Pinang, the organizers of the general election interpret the regulations by themselves without any coordination with other institutions. Some complaints that they have to pass to the upper level of the institution have been expired then.

The recruitment of personnel, in this sense, has to consider the background of candidates and their motivations to become general election organizers. The failure in selecting the right candidate will lead to the loss integrity of the organizers. Some previous studies are concerned with the dimension of capacity more holistically. According to Eisinger (2002), the candidates of organizers have to have skills in managerial, leadership, and good relationship with an external organization.

Bismar Arianto, who had been a member of the selection committee of General Election commission member, argues that to anticipate the ethics violation, the candidates' motivations have 
to be looked into. The same opinion has been conveyed by Arison, a member of the General Election Commission at the provincial level of Riau Islands when he was a member of the selection committee for General Election members at the district level. The consideration is that the candidates' motivations are not merely looking for jobs or to improve their lives, but to implement general election according to rules.

A team that can implement a quality general election has to be formed by quality human resources, who can accomplish their task based on their capacity and rationality (Idea, 2012). Bismar argues that the person whose motivation is to make living, will not accomplish his/her work if can earn more income from another offer. Arison's view about looking at the motivation of candidates of organizers of the general election has contributed to the efforts in selecting the candidates who want to dedicate to improve the quality of democracy. A sense of belonging has to be embedded to those who want to join the general election agencies so they will consider the institutions as their own and follow the rules in implementing the election.

Another opinion is from the member of TPD of the Riau Islands province Dr. Neng Suryanti, who argues that the causes of an ethics violation in the implementation of the general election are the neglect of regulation and ethics by the organizers of a general election due to other interests. A high salary cannot guarantee the organizers following the rules. The integrity and credibility of the organizers are determined by their conscience. The violation in this respect will cause in the sanction from society, such as distrust.

One cause of violation of regulation in the implementation of the general election in the Riau Islands is bribery given by the participants of the election. The participants give the amount of money to the organizers to change the results of the election for their interests or the interests of a certain group. Therefore, a high salary cannot guarantee the organizers of general election maintaining their integrity.

The external factor cannot be separated from the internal factor, such as the low capacity of general election agencies, which opens an opportunity to be influenced by an external situation. The external factor is event or situation out of general election institutions, which can influence the performance of the institutions (Usman, Liando \& Rumawas, 2016). In an interview with a specialist on general election Dr. Dewi, the author notices an opinion that external factor that influences the ethics violation by the general election organizers is a disagreement between the general election agencies (such as General Election Commission/KPU) and supervising body at the provincial level (BAWASLU) on the interpretation of guideline in the implementation of the general election. The dissenting opinion on the interpretation can obstruct the process of the general election. Less knowledge on the regulations often obstructs the process of implementation of the general election and particular stages that have been scheduled and planned according to the regulation before.

Moreover, political intervention from the political party or candidates as participants also influences the credibility of the organizers of the general election. In this sense, the political interests of candidates or political parties are stronger than the organizers themselves. This is also due to the involvement of the organizers in the political arena furtively.

The improvement of capacity or general election organizers, in this respect, will give an influence. Felstead (2010), in his study, describes that the trainees (either in education or training ) will improve their performance quality and are 
influence by other colleagues and their involvement in the organization. Technical training on ethics for the general election organizers in this sense will give more knowledge to solve problems that they face. Furthermore, the organizers of general elections have to limit themselves in serving the participants of the general election. The limitation here is not giving a chance for the participants (candidates) to influence the organizers for their political interests.

Another factor that becomes the cause of violation of ethics is intimidation or intervention from external agencies or persons who have political influence in their region. The feeling of being intimidated and inconvenience influence the organizers or general election and the implementation of the election. The election, in this sense, is hardly implemented well with integrity and tend to win the interests of certain participants.

Related to the external influence or external factor, academics and experts on general election Neng Suryanti, Oksep, dan Arison give an opinion that the organizers have to be cautious of external factors in every stage of implementation of the general election that has to be transparent so that civil society can participate and monitor the participants of the election. Even from the recruitment of general election organizers, which has to ensure that the candidates have no relationship with any political party. If public participation is good, for instance, the recruitment process will be transparent and people will know the track record of candidates.

Another expert on general election Dewi Haryanti argues that the cause of violation of ethics in the general election is a disagreement between two general election agencies, namely General Election Commission (KPU) and Supervisor of General Election (BAWASLU) on the way of monitoring the process of the general election. The two institutions have their interpretations of regulations or norms that have to be followed in organizing the general election. In this case, the should have discussed otherwise the implementation will not succeed.

Moreover, the organizers or general election are influenced by political interests in making a decision and its implementation in every stage of the general election. Political influence on the organizers can disturb the independency of the organizers and low their credibility. For instance, they discriminate against one candidate and take a side on the other candidate. This happens due to tot he organizers taking part in political interests and facilitate them in the process of the general election.

The third approach is from infrastructure (for example, facilities). This approach looks at the infrastructure, facilities, in the workplace of the general election agencies, such as the General Election Commission (KPU) and Supervisor of General Election (BAWASLU). The approach looks into the fulfillment of the facilities in supporting the implementation of the general election.

Inadequate facilities will affect performance and productivity. Lack of skills in operating facilities will hinder and allow mistakes in work. The ability to utilize the facilities will improve the effectiveness and efficiency of performance. (Lupiyoadi, 2006). Therefore, it is related to operational capability. Office building infrastructure for the election organizers in the Riau Islands province is inadequate.

The fourth approach uses the financial dimension that cannot be separated from financial management that is managed to support routine activities and stages of election activities. Based on information obtained in organizing the 2014 Legislative Elections and the 2015 Regional Head Elections, there were no reports that violated the provisions of the legislation. The electoral budget 
management process runs according to the established technical guidance mechanism. Financial management is managed by the General Election Commission (KPU) secretariat and the Bawaslu Secretariat at each level.

The study of the financial dimension in the administration of elections did not reveal any deviation in the use of the budget in the implementation of both Legislative and Gubernatorial elections. In the author's view, the election organizers indicated an ethics violation, such as receiving money from participants in the election. In the case of violations of the ethics of the general election in Karimun Regency, it is not based on financial problems. Reports of complaints raised by election participants relate to ethical norms in speaking, dressing, and dissatisfaction with vote counting. But unlike the case that occurred in Batam, there are allegations of bribery received by the election organizers. According to one informant in the field and the public opinion, the election organizers cannot commit violations concerning the code of ethics with just or sincerity to side with one of the election participants without compensation. Willing to violate the code of ethics by carrying a ballot box without security outside the Batam City KPU office, for instance.

\section{CONCLUSION}

This research analyzes the cases of violation of ethics in the implementation of the General Election in the organizational frame, both in the 2014 General Legislative Election and 2015 Gubernatorial Election in Riau Islands Province, which is particularly held in Tanjungpinang city, Batam city, and Karimun District. All cases show interrelatedness oft he violation with the human resources' capacity.

By observing the organizational capacity, human resources dimension, external influence, infrastructure, and financial factors, this research finds that human resources are the dominant factor that causes the violation of ethics in the implementation of the General Election. This is due to the lack of knowledge in understanding the rules of the General Election that brings the organizers to the violation. Related to human resources, some research findings confirm the factors that drive an individual actor has been on the trial of ethics in the court of DKPP.

Lack of knowledge about regulations related to general election and interpretation based on assumption will lead to the violation of the rules as implemented in the hierarchy from central to the district level. One example is in the case of a lawsuit due to mistake in the recapitulation, which is responded by ignoring the recommendation of the supervising body (PANWASLU) to remedy the recapitulation Pemungutan Suara Ulang (PSU).

Besides, the causes of violation of ethics could be traced to the very beginning, which is the recruitment of the candidates of general election organizers. For example, a candidate has been accepted to become personnel of a general election commission (KPU) to serve the interests of participants, such as a political party or legislative candidate. This implements the general election is not fair. This shows that incorrect recruitment will lead to a low-quality general election. This is due to the transaction between the organizers and the participants. The organizers, who have passed the recruitment process will pay the assistance of people who are running in the election.

Besides, external factors also play certain roles in the violation of ethics in which the organizers of the general election are committed. Ethics violation tends to be pushed by political patronage and family relationship. The organizers of the general election tend to take aside the participants (legislative candidate or candidate of the governor) who have a 
family relationship or political patronage with them.

However, the external factor can minimize ethics violations through the involvement of society in following and monitoring the process of the general election. In this sense, people will give a response to any case of violation, either comments or critics, which can develop a democratic process in their area. The involvement of external institutions will contribute to increasing the credibility and integrity of the general election agencies. The independency of general election organizers from the political influence of participants (political parties and candidates) will improve the credibility and integrity of the general election agencies.

\section{ACKNOWLEDGMENT}

The author thanks the General Secretariat of General Election Commission of the Republic of Indonesia, which has granted me a scholarship, Beasiswa Tata Kelola Pemilu Batch III T.A 2017.

\section{BIBLIOGRAPHY}

Bogdan \& Taylor (1975). Metode Penelitian Kualitatif, Remadja Karya, Bandung.

Christensen, R.K., \& Gazley, B. (2008). Capacity for Publik Administration: Analysis of Meaning. Public Administration and Development, (28), 265-279.

Creswell, J.W, (2013). Qualitative Inquiry \& Research Design: Choosing Among Five Approaches (3rd ed.) Thousand Oaks: Sage Publications.

Creswell, J.W, (2015). Penelitian Kualitatif \& Desain Riset: Memilih Diantara Lima Pendekatan. Pustaka Pelajar, Yogyakarta.
Eisinger, P. (2002). Organizational Capacity and Organizational Effectivitiveness Among Street- Level Food Assistance Programs. Sage Publications, 1 (31):115-130, California.

Felstead, A., Gallie, D., Green, F., Zhou, Y. (2010), Employee Involvement, The Quality of Traning, and The Learning Environment: An Individual-Level Analysis. The International Journal of Human Resource Management, (21)10: 1667-1688.

Idea, I. (2012) Manajemen Kepemiluan Selama Masa Transisi, Tantangan dan Peluang. International Institue for Demodracy and Electoral Assistence, Internasional IDEA.

Pratama, A. (2017) Integritas Penyelenggara Pemilu. Studi Kasus Badan Pengawas Pemilu Provinsi Jawa Barat, Pascasarjana Fisip Unpad, Bandung.

Lupiyoadi, H. (2006). Manajemen Pemasaran Jasa, Salemba Empat, Jakarta.

Newstrom, J. Davis, K. (2000). Prilaku Dalam Organisasi Edisi Ketujuh, Erlangga, Jakarta.

Rahardjo, S. (2010) Sosiologi Hukum Esai-Esai Terpilih, Genta- Publishing, Jakarta.

Rizal, M., R, (2017), Kewenangan Dewan Kehormatan Penyelenggara Pemilu (DKPP) Dalam Penyelesaian Pelanggaran Pemilihan Kepala Daerah Tahun 2015 oleh Anggota Komisi Pemilihan Umum Kabupaten Kapuas Hulu, Jurnal Nestor Magister Hukum, (1) 1: Pontianak

Sardini, N.H. (2014). Kepememinpinan Pengawasan Pemilu: Sebuah Sketsa, Rajawali Pers, Jakarta.

Usman, C., Liando, D.M, Rumawas, W. (2016) Pengaruh Lingkungan Internal dan External Organisasi Terhadap Kinerja. Jurnal Ilmu Sosial dan Pengolahan Sumber Daya Pembangunan: 19-33

York, P. (2010). The Sustainability Formula: How Nonprofit Organization Can Thrive in the TCC Group. New York.

Zetra, A. Chatra,E „,Sari, Y (2017). Pelanggaran Kode Etik Berat oleh Anggota KPU Kabupaten/Kota di Provinsi Sumatera Barat pada Pemilu Tahun 2014 dan Pilkada Tahun 2015, Jurnal Ilmu Sosial Fisip Universitas Andalas: $20-30$ 